\title{
The potential of naturally occurring bacteria for the bioremediation of toxic metals pollution
}

\author{
Amit Vashishth ${ }^{1}, *$ Nimisha Tehri ${ }^{2}$ and Pawan Kumar ${ }^{1}$ \\ ${ }^{1}$ Department of Biotechnology. MMU. Mullana. Haryana. 133207 India. Email: \\ amitvashishth659@gmail.com. \\ ${ }^{2}$ Department of Microbiology. IIMT University. Meerut. UP. 250001 India.
}

\begin{abstract}
An increase in industrialization and various kind of human activities added a huge amount of toxic heavy metals in the soil. As a result, toxic heavy metals in the environment may be adversely affects human being and aquatic ecosystem. Thus, it is very essential to understand mechanism of bioremediation through eco-friendly agent i.e. bacteria. Accumulation of high metal concentrations in soil above threshold limit causes lethal to bacterial communities in the environment. Few bacteria develop resistance mechanism to tolerate these toxic heavy metals and contain various methods to respond the metal stress. The present review emphasizes to understand the mechanism of bacterial resistance against toxic metals. Moreover, mechanism of bioaugmentation, biosorption, and bioaccumulation methods also described clearly.
\end{abstract}

Keywords: Bioremediation; Xenobiotic compounds; Heavy metals; Bacteria; Tolerance; PAHs.

\section{Introduction}

Increase of agriculture and manufacturing industries have increased the emission of several vital xenobiotic compounds in the environment. Excess amount of toxic metal waste has decrease the level of drinking water in the environment and thus resulting in reduction of crop production
(Kamaludeen et al., 2003). Bioremediation exploits mainly bacteria to remediate the contaminated water and soil (Strong and Burgess, 2008). It relies on promoting the growth of bacterial consortia which is indigenous to the contaminated sites (Agarwal, 1998). Bacterial consortia can be develop through addition of nutrients by optimum temperature and moisture 
conditions (Hess et al., 1997; Smith et al., 1998). Bacteria take contaminants as a nutrient source in bioremediation technology (Tang et al., 2007).

Bioremediation technology is used to remediate contaminated environment through bacterial consortia. Several scientists (Odu, 1978; Sloan, 1987; Ijah and Antai, 1988; Okpokwasili and Okorie, 1988; Barnhart and Meyers, 1989; Anon, 1990; Pritchard, 1991; Pritchard and Costa, 1991; Ijah, 2002, 2003) have revealed different applications of bacteria in the bioremediation of oil pollution with good results. Use of shellfish polluted by polycyclic aromatic hydrocarbons could be the reason of lung cancer in human beings (Law and Klungsoyr, 2000; Gaspare et al., 2009). Water contaminated through petroleum oil and hydrocarbons is very common in developed countries and it is very harmful to human health and aquatic ecosystem (Al-Baldawi et al., 2015). Biological bioremediation is an ecofriendly process which is very essential to remediate polluted aquatic ecosystem (Head and Swannell, 1999; Head et al., 2006; Beolchini et al., 2010; Dell'Anno et al., 2012). Furthermore, several authors demonstrated that petroleum pollution is very toxic to the environment (Lyons et al., 1999; Janjua et al., 2006). But fortunately, bacteria use these contaminants as a nutrient source (Atlas 1995; Oliveira et al., 2012). Many researchers demonstrated that both protozoa and algae are not responsible to degrade hydrocarbons (O'Brien and Dixon, 1976; Bossert and Bartha, 1984; Saadoun and Al-Ghzawi, 2005). Hassan et al. (2016) reviewed the various processes involved in bioremediation coupled with electrokinetics. Currently, Igiris et al. (2018) demonstrated the bioremediation of heavy metals contaminated ecosystem from tannery wastewater. Saranya et al. (2017) also screened Vibrio fluvialis from industrial effluents for the bioremediation of mercury.

\section{Background of heavy metals}

Heavy metal usually occurs in its two forms i.e. bio-available and nonbioavailable forms. Their mobility depends on positive and negative charged component of salt (Sposito 2000). Cation exchange capacity, clay minerals, redox potential, buffering capacity, $\mathrm{pH}$, organic matter, water content, temperature and bacterial activities determines the bio-availability of heavy metals in soil (Khan et al. 2009; Brown et al. 1999). Metals occur in soluble cationic forms under aerobic conditions, while on other side, found in carbonate or sulphide precipitates during anaerobic conditions. Khan et al. (2009) and Brown et al. (1999) studied the bio-availability of few heavy metals in following order: Zinc > Copper > Cadmium > Nickel. Nevertheless, the concentration of heavy metals varies drastically in the ecosystem. Therefore, these secondary pollutants get accumulate into food chain and finally into human food. Contamination of agriculture soil with heavy metals has become a major problem for the sustainability of the environment. Thus, assessment of heavy metal bioavailability enables to evaluate the impact of metals on soil bacteria and it demonstrate the use of bioremediation technologies to clean heavy metals pollution from soil. Lead and Cadmium are main two heavy metals which are the most toxic because they have no role in the metabolism of living beings. Both said metals are distributed hugely in the environment so it is very important to remediate the environment from these two metals.

\section{Lead}

Lead $(\mathrm{Pb})$ is very persistent kind of secondary pollutant in environment. Human being is exposed to $\mathrm{Pb}$ through paint, cosmetics, folk remedies, lead batteries and other food supplements etc. ATSDR (2007) reported that inorganic $\mathrm{Pb}$ usually absorb by oral and dermal exposure through the respiratory 
system. Absorption of lead acetate and lead chloride was observed higher in children than in adults (ATSDR, 2007). According to ATSDR (2007) in adults, around $92 \%$ of body burden of $\mathrm{Pb}$ remains confined to bones as compared to $77 \%$ in children. $\mathrm{Pb}$ is a ubiquitous secondary pollutant which is well known to change the hematological system by inhibiting the function of several enzymes involved in the biosynthesis of haem (Hernberg and Nikkanen, 1970; Millar et al., 1970). Pb inhibits the entry of calcium ions $\left(\mathrm{Ca}^{2+}\right)$ into cells with synaptogenesis. In blood, $\mathrm{Pb}$ is primarily found in red blood cells (RBC) and also responsible for the inhibition of human neurotransmitter system. $\mathrm{Pb}$ destabilizes the cellular membrane of RBC and reduces the fluidity of cell membrane and as a result rate of erythrocyte hemolysis increases which leads to anemia (Bellinger and Bellinger, 2006; Needleman, 2004). Pb also mimics to $\mathrm{Ca}^{2+}$ and disturb calcium homeostasis which leads to the production of neurotoxin having adverse effects on central nervous system. Pathogenesis of $\mathrm{Pb}$ toxicity is multifactorial and it induces oxidative stress by generation of reactive oxygen species (ROS). It reduces antioxidant defense mechanism of cells by interrupting with essential metals needed for enzyme activities and also alters membrane integrity and fatty acid composition (Gurer and Ercal 2000). Metabolism of inorganic $\mathrm{Pb}$ composed of formation of complexes with protein and non-protein ligands. Inorganic $\mathrm{Pb}$ compounds are actively metabolized in liver through oxidative dealkylation by P450 enzymes.

\section{Cadmium}

Cadmium (Cd) occurs naturally in the earth's crust in association with copper, zinc and lead ores. It is generally found in cadmium-nickel battery manufacture, nonferrous metal, waste incineration, refining, phosphate fertilizers and disposal of environment. Cadmium expose mainly through cigarette smoke, chocolate, mushroom and seafood in human beings (EFSA, 2009). Excess accumulation of Cd salt causes severe problems like osteoporosis, anemia and renal tubular injury (Jarup, 2003). Miura (2009) revealed that $\mathrm{Cd}$ is a potent carcinogen which associated with cancer of kidney, pancreas and lung and was classified by International Agency for Research on cancer. Still, molecular mechanism of $\mathrm{Cd}$ based carcinogenesis is not yet understood. Replacement of zinc in zinc finger structures was planned to understand the mechanism of mutagenic effect of Cd salt.

\section{Mechanism of bacterial resistance against heavy metal stress \\ Accumulations of toxic heavy} metals in the soil and their absorption by the plants have become very important concern for environmental scientist. Unlike other secondary pollutants, toxic heavy metals could also biodegrade to less toxic products (Kumar et al. 2011). Some heavy metals e.g. nickel, zinc, copper and chromium are essential micronutrients which require for the growth of plants, animals and microorganisms (Olson et al. 2001). While, cadmium, lead and mercury have no biological or physiological role in living beings (Gadd 1992). Therefore, higher concentration of cadmium, mercury and lead have very adverse effects on the bacterial community in soil by three different ways, (1) It leads to reduction of total bacterial biomass (Giller et al. 1998) (2) It reduces the population of specific bacteria (Chaudri et al. 1993) (3) It alters the structure of bacterial community (Gray and Smith 2005). Hence, at higher concentration of toxic metal ions may be inhibit the growth of bacterial population through interruption of normal activities as shown in figure 1. But, few potential bacteria can develop resistance or tolerance against high concentration of metals. Generally, resistance may be defined as ability to deal with pollutant 
toxicity with help of intrinsic properties of bacteria. While, tolerance is the phenomena in which bacteria get survive even in higher concentrations of heavy metals by the mechanism of detoxification (Ahemad et al. 2009). Therefore, toxic heavy metals needed to either removed completely or transformed to be less toxic forms. Bacteria develop several mechanisms to acclimatize under metal stressed conditions to tolerate the uptake of toxic metal ions (Nies 1999). Five different mechanisms include following processes;
(1) Accumulation-Bacteria forms complex with metal binding proteins (e.g. metallothionins, a low molecular wt. proteins) (Kao et al. 2006; Umrania et al. 2006), (2) Exclusion-Toxic metal ions are removed from target sites, (3) Biotransformation-Toxic metal ions are allowed to convert into toxic forms, (4) Methylation and Demethylation-One or more of these defence mechanisms allows bacteria to function metabolically in metals polluted environment, (5) Extrusion-Metals are pushed out of the cell by chromosomal mediated events.

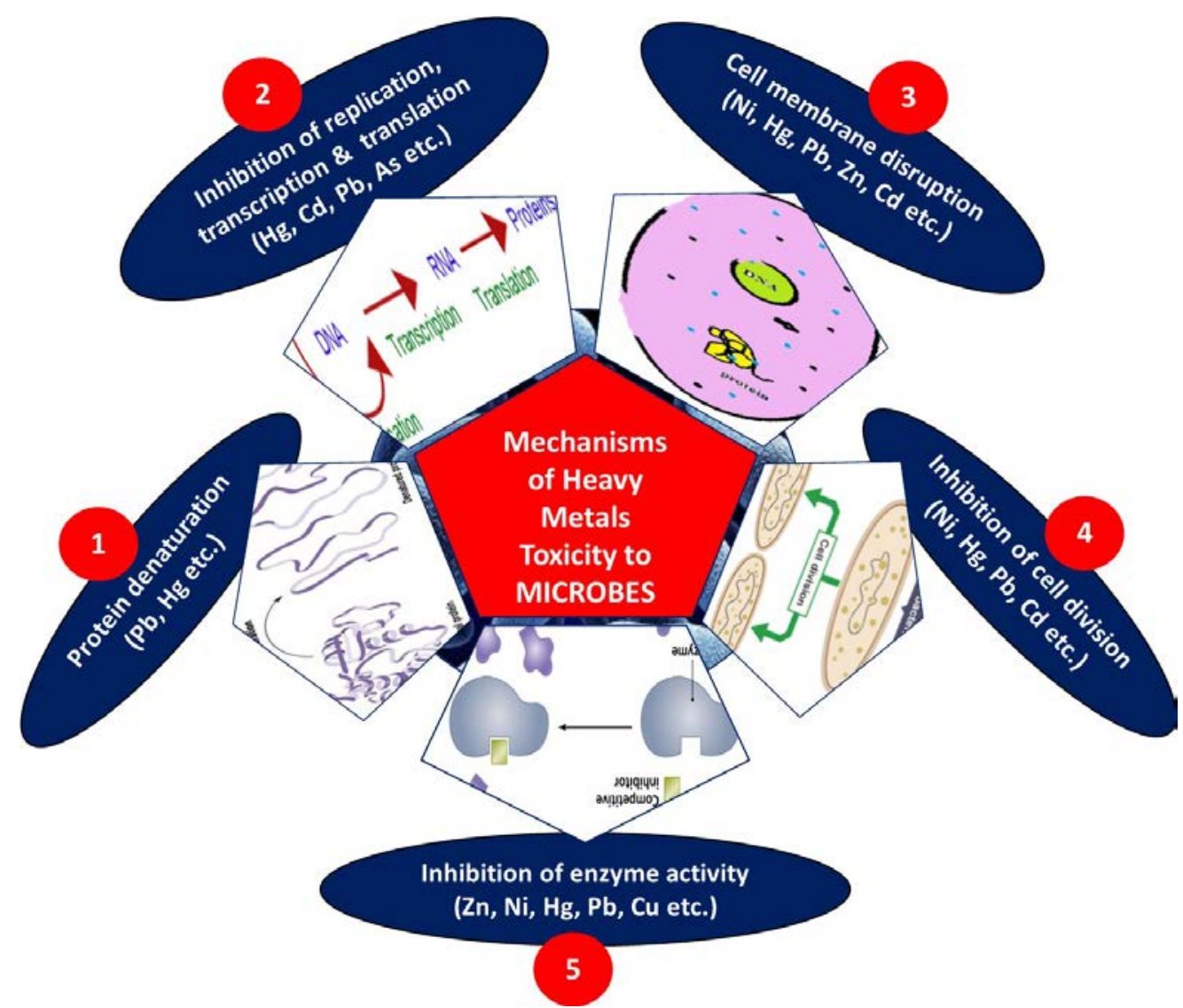

Figure 1. Mechanisms of Heavy metal-toxicity to microorganism.

Bacterial resistance mechanism is usually present on plasmid and chromosome part of cell. Bacteria acclimatize their resistance against heavy metals through gene transfer or spontaneous mutation. Nies (1999) demonstrated CZC metal tolerance mechanism in gram negative bacteria i.e. Ralstonia eutropha and CZC genes are responsible for a cation-proton antiporter (czcABC), which excludes zinc, cadmium and cobalt metals. A similar 
kind of mechanism was reported in Alcaligenes xylosoxidans which provides resistance against nickel, cobalt and cadmium. Furthermore, Roane and Pepper (2002) reported that cadmium resistance mechanism is different in gram positive bacteria (e.g. Staphylococcus, Bacillus or Listeria) and it was through $\mathrm{Cd}$ efflux ATPase. They demonstrated plasmid encoded resistance mechanism through ATPase, chemiosmotic ion or proton pumps in chromium, arsenic and cadmium in some bacteria. Lloyd and Lovley (2001) studied unique properties of bacterial resistance for the remediation of toxic metal contaminated sites. Therefore, bacteria can interact among heavy metals through several mechanisms. There is a list of bacteria which are able to accumulate heavy metals toxicity (Table 1).

Table 1. List of some comprehensively investigated heavy metal accumulating bacteria. Metals, bacteria and their source, MRL/uptake efficiency and removal percentage with removing time has been shown.

\begin{tabular}{|c|c|c|c|c|c|}
\hline Metal & Microorganism & Source & MRL/uptake efficiency & Removal (\%) & References \\
\hline \multirow[b]{2}{*}{$\mathrm{Cd}$} & Bacillus strain $\mathrm{H} 9$ & Metal-contaminated soil & $284 \mu \mathrm{g} / \mathrm{mL}$ & $35(50 \mathrm{~h})$ & Roane et al., 2001 \\
\hline & Aspergillus terreus & $\begin{array}{c}\text { Industrially polluted } \\
\text { sediments }\end{array}$ & $124 \mathrm{ppm} / \mathrm{g}$ & 72 (14 days) & Massaccesi et al., 2002 \\
\hline \multirow{2}{*}{$\mathrm{Cr}$} & Pseudomonas aeruginosa & Wastewater & $0.079 \mathrm{mg} / \mathrm{mL}$ & 46 ( 2 days) & Hassen et al., 1998 \\
\hline & Aspergillus niger & Acquired & $5.2-6.5 \mathrm{mg} / \mathrm{g}$ & $22-35$ ( 7 days) & Dursun et al., 2003 \\
\hline \multirow[t]{2}{*}{$\mathrm{Pb}$} & $\begin{array}{c}\text { Pseudomonas aeruginosa } \\
\text { PU21 (Rip64) }\end{array}$ & - & $0.6 \mathrm{mg} / \mathrm{mL}(112 \mathrm{mg} / \mathrm{g})$ & 82 ( 3 days) & Chang et al., 1997 \\
\hline & Aspergillus niger & Acquired & $5.2-33.4 \mathrm{mg} / \mathrm{g}$ & 14-86 (7 days) & Dursun et al., 2003 \\
\hline \multirow[b]{2}{*}{$\mathrm{Cu}$} & Thiobacillus ferrooxidans & Adopted & $0.12 \mathrm{mg} / \mathrm{mL}(704 \mathrm{mg} / \mathrm{g})$ & $24(18 \mathrm{~min})$ & Boyer et al., 1998 \\
\hline & $\begin{array}{c}\text { Schizosaccharomyces } \\
\text { pombe }\end{array}$ & Acquired & $0.5-1.2 \mathrm{mg} / \mathrm{g}$ & $12-24$ ( 5 days $)$ & Donmez and Aksu, 1999 \\
\hline \multirow{2}{*}{$\mathrm{Ni}$} & Pseudomonas spp. & Local isolate & $72.9 \mathrm{mg} / \mathrm{g}$ & 97 ( 5 days) & Magyarosy et al., 2002 \\
\hline & Candida spp. & Sewage & $10.2-42.4 \mathrm{mg} / \mathrm{g}$ & $28-58$ ( $5-12$ days $)$ & Donmez and Aksu, 2001 \\
\hline
\end{tabular}

Abbreviations: MRL: Maximum Resistance Level.

\section{Classification bioremediation}

Bioremediation can be classified to different methods such as biosorption, biomineralization, bioaccumulation, bioleaching and biotransformation. Bacteria use the heavy metals from soil as nutrients source for their growth and development. They have capability to reduce or oxidize transition metals. Bioremediation can be made successful by understanding the mechanism of bacterial growth in the contaminated sites. Sikkema et al. (1995) revealed that bacterial cells develop defense mechanisms against contaminants by forming outer cell membrane protective material.

\section{Biosorption}

Heavy metals form interactions with the binding sites present in the cellular structure of bacteria through biosorption method. Extracellular polymeric substances (EPS) of bacterial cell walls have significant properties for metal adsorption and EPS revealed a great ability to form complex through specific mechanisms for the precipitatation of metals (Guine et al., 2006; Comte et al., 2008; Fang et al., 2010). Fang et al. (2011) characterized and quantified proton and adsorbed on bacterial cells and studied the importance of EPS molecules to remove the toxic metal. Therefore, it is very 
important to understand genomic characteristic and metabolic pathway of bacteria used in metal adsorption (Kinya and Kimberly, 1996; Carter et al., 2006; Gan et al., 2009; Haritash et al., 2009; Onwubuya et al., 2009).

\section{Metal precipitation}

Several bacteria can be used to immobilize toxic heavy metals through the process of their lower redox state and producing less bioactive metal species. Metal precipitation is a very common activity which is the result of reduction of metabolic processes unrelated to the transformed metals. Roane and Pepper (2000) demonstrated that $\mathrm{Cr}(\mathrm{VI})$ get reduces to insoluble $\mathrm{Cr}$ (III) through bacterial respiration or by indirect reduction of sulphide. Metal precipitation strategy has become more interested for environmental scientist by the formation of metal sulphides and ferrous through indirect reduction. However, dissimilatory metal reduction can also be safely used for decontamination.

\section{Bioremediation by physio-bio- chemical mechanism}

Biosorption process involves

higher affinity of a biosorbent for metal ions, continued until equilibrium is established between two components (Das et al. 2008). Later Chen and Wang (2007) and Talos et al. (2009) revealed that Saccharomyces cerevisiae acts as a biosorbent for the removal of $\mathrm{Cd}$ and $\mathrm{Zn}$ ions through ion exchange mechanism. Cunninghamella elegans emerged as a promising sorbent against heavy metals released through textile waste water (Tigini et al., 2010). Both active and passive modes of toxic metal bioremediation may be called bioaccumulation (Brierley, 1990). Moreover, Pinedo et al. (2009) revealed that fungi have potential to act as biocatalysts to access heavy metals and convert them into less toxic form. Some fungi such as Botryosphaeria rhodina, Pleurotus pulmonarius and Allescheriella species have metal binding capacity (D'Annibale et al., 2007). Lead contaminated soils can be biodegraded by fungal species e.g. Aspergillus parasitica and Cephalosporium aphidicola through biosorption process (Tunali et al., 2006; Akar et al., 2007). Hg tolerant fungi (Neocosmospora vasinfecta and Verticillum terrestr) were able to biotransform $\mathrm{Hg}^{2+}$ state to its less toxic form (Kelly et al., 2006). Generally, contaminants are hydrophobic in nature and these materials appear to be taken up by bacteria through the secretion of few biosurfactants. Biosurfactants forms stronger ionic bonds with heavy metals and form complexes due to low interfacial tension (Thavasi, 2011). Bioremediation involves aerobic or anaerobic microbial activities. Aerobic degradation adds oxygen into the reactions mediated through different enzymes like hydroxylases, oxidative dehalogenases and chemically reactive oxygen. Anaerobic degradation of pollutants involves initial activation reactions through oxidative catabolism which is mediated by anoxic electrons. Immobilization is the process in which mobilization of toxic metals get reduce from polluted sites through physical or chemical state. Solidification treatment could be used to mixing of chemical agents at pollutants sites (Evanko and Dzombak, 1997). Bacteria get mobilize heavy metals from contaminated sites through chelation, redox transformation and methylation of toxic metals. Furthermore, Garbisu et al. (2001) revealed that heavy metals can't be destroyed completely, but metals could be converted to its precipitated and less toxic forms. Bacteria remove toxic metal ions by using the mechanism which utilizes to derive energy from redox reactions in enzymatic and nonenzymatic processes. Silver (1996) studied two mechanisms which are responsible for the development of resistance in bacteria: 1 . Detoxification is the process in which toxic metal gets transform to less toxic form. 2. Active 
efflux pumping of toxic metal ions from cell. Bacteria act as an oxidizing agent for heavy metals and lose electrons, which are accepted by alternative electron acceptors e.g. nitrate, sulphate and ferric oxides. Oxygen acts as an electron acceptor in aerobic conditions, while it oxidizes inorganic contaminates in anaerobic conditions. Bacteria take energy for their growth through oxidizing organic compound from Mn(IV) or Fe(III) as an electron acceptor (Lovley and Phillips, 1988). Anaerobic degradation of organic pollutant is stimulated with higher availability of iron for bacterial reduction (Spormann and Widdel, 2000). Lovely (2002) demonstrated that metals are used as terminal electron acceptors and known as dissimilatory metal reduction.

Bacteria convert the state of metals and reduce the uranium phase from $\mathrm{U}^{6+}$ to $\mathrm{U}^{4+}$ (Lovley et al., 1991). Different defense mechanisms viz., exclusion, formation of binding proteins and complex formation decrease the effect of stress produced from toxic heavy metals (Gómez Jiménez-T et al., 2011). Heavy metal accumulation has been studied through expression of metal binding protein and peptides in bacteria (Cobbett and Goldsbrough, 2002). The expression of smtA gene and production of metal binding protein was studied in
Synechococcus sp. (Huckle et al., 1993). Later, Ralstonia eutropha was genetically manipulated to express mouse metallothionein protein on the surface of cell and reduce the toxic effect of the $\mathrm{Cd}^{2+}$ from the contaminated site (Valls et al., 2000). Mejare and Bulow (2001) studied the expression of different proteins and peptides to regulate the range of accumulation of cadmium in Escherichia coli. Natural tolerance pathways for metal toxicity have been regulated by metalloregulatory protein in bacteria (Singh et al., 2008).

\section{Genetic Engineering for bioremediation processes}

Genetically modified microbes are organisms in which genetic material has been manipulated using recombinant DNA technology (RDT) to identify competent strain to remediate hazardous contaminants present in ecosystem (Sayler and Ripp, 2000). The genetically engineered potential bacteria which remove the toxicity of heavy metals are given in Table 2. Nowadays, genetic engineering has been developed different bacterial biosensors to measure the level of contamination in environment. Several biosensors have been made to estimate heavy metal concentration like cadmium, mercury, arsenic and copper (Verma and Singh, 2005; Bruschi and Goulhen, 2006).

Table 2 Genetically engineered bacteria for bioremdiation of heavy metals.

\begin{tabular}{l|c|c|c|c|c}
\hline Heavy metal & $\begin{array}{c}\text { Initial conc. } \\
(\mathbf{p p m})\end{array}$ & $\begin{array}{c}\text { Removal } \\
\text { efficiency (\%) }\end{array}$ & $\begin{array}{c}\text { Genetically engineered } \\
\text { bacteria }\end{array}$ & Expressed gene & References \\
\hline $\mathrm{As}$ & 0.05 & 100 & E. coli strain & Metalloregulatory protein ArsR & Kostal et al. 2004 \\
\hline $\mathrm{Cd}^{2+}$ & - & - & E. coli strain & SpPCS & Kang et al. 2007 \\
\hline $\mathrm{Cr}^{6+}$ & $1.4-1000$ & 100 & Methylococcus capsulatus & CrR & Hasin et al. 2010 \\
\hline $\mathrm{Cr}$ & - & - & P. putida strain & Chromate reductase (ChrR) & Ackerley et al., 2004 \\
\hline $\mathrm{Cd}^{2+}, \mathrm{Hg}$ & - & - & $\begin{array}{c}\text { Ralstonia eutropha } \text { CH34, } \\
\text { Deinococcus radiodurans }\end{array}$ & merA & Valls et al. 2000 \\
\hline $\mathrm{Hg}$ & - & - & E. coli strain & Organomurcurial lyase & Murtaza et al., 2002 \\
\hline $\mathrm{Hg}$ & 7.4 & 96 & E. coli jM109 & Hg2+ transporter & Zhao et al., 2005 \\
\hline $\mathrm{Hg}$ & - & - & Pseudomonas K-62 & Organomercurial lyase & Kiyono and Pan, 2006 \\
\hline $\mathrm{Hg}$ & - & - & Achromobacter sp AO22 & mer & Ng et al. 2009 \\
\hline $\mathrm{Ni}$ & 145 & 80 & P. fluorescens 4F39 & Phytochelatin synthase (PCS) & Lopez et al. 2002 \\
\hline
\end{tabular}

\section{Bioremediation by bio- augmentation}

Several authors demonstrated that addition of nutrients is essential to enhance bacterial growth and biodegradation activity. Wu et al. (2012) revealed the surface activity of salt tolerant Serratia Spp. and crude oil 
degradation in saline soil. The novel strain of Serratia Spp BF40 was isolated from crude oil contaminated soils and evaluated for its surface activity, salt tolerance from saline soil. The authors also suggested that strain reduce the surface of oily soil surface and concluded that using bacterial strain with biosurfactant producing capability was efficient. Candida tropicalis (SK 21 strain) was used for bio-augumentation ability by Fan et al. (2013). Genetic engineering of rhizospheric bacteria with plant associated degradation of contaminants has become new technology to remediate metal contaminated sites (Divya and Kumar, 2011). Escherichia coli and Moreaxella sp. expressed phytochelatin 20 on cell surface to accumulate $\mathrm{Hg}$ and Cd (Bae et al., 2001, 2003). Several scientists tried to understand molecular approaches in Escherichia coli, Bacillus subtilis and Pseudomonas putida.

\section{Bio-stimulation by using inorganic nutrients}

Inorganic fertilizers have been utilized in the form of bio-stimulation agents globally. Chorom et al. (2010) demonstrated the efficiency of inorganic fertilizer to enhance microbial degradation of petroleum hydrocarbons in contaminated soil. Agarry and Ogunleye (2011) used inorganic fertilizers as independent biostimulation variables. Venosa et al. (2002) reported that bacteria are easily degraded light end hydrocarbon than heavy end hydrocarbons. Thus, addition of inorganic fertilizers was more effective in the improvement of biological degrading activity.

\section{Conclusions}

Bioremediation is a very important tool used to clean up the contaminants present in the environment. The initiation of bioremediation has been started for several years. However, some applications are relatively new and many other applications are emerging or being developed. Bioremediation occurs when micro-organisms can biodegrade the secondary pollutant like heavy metals, polycyclic aromatic hydrocarbons and pesticides. This process may be aerobic or anaerobic that depends on the availability of micro-organisms and electron acceptors. These methods of bioremediation may be natural or improved by engineered bioremediation. This technology is very efficient and cost effective to treat contaminated water and soil. This review concluded that organic and inorganic nutrients could promote bacterial growth and degradation of toxic metal pollution in the environment. We also elucidated the fact that biodegradation of toxic heavy metals in the soils is feasible with bacterial metabolism.

\section{Acknowledgement}

The authors gratefully
acknowledge all the staff of MMU,
Univesity, Mullana, for the general
support provided, when it was required.

\section{Conflict of interest}

The authors declare that there is no conflict of interest.

\section{References}

Agarry, S. E.; Owabor, C. N. Anaerobic bioremediation of marine sediment artificially contaminated with anthracene and naphthalene. Environmental Technology, v. 32, p. 1375-1381, 2011.

Agarwal, $\quad$ S. K. $\quad$ Environmental Biotechnology. 1. ed. New Delhi, India: APH Publishing Corporation, 1998.

Ahemad, M.; Khan, M. S.; Zaidi, A.; Wani, P. A. Remediation of herbicides contaminated soil using microbes. In: Khan, M. S.; Zaidi, A.; Musarrat, J. (Eds.). Microbes in sustainable agriculture. New York: Nova Science Publishers, 2009. p. 261-284.

Akar, T.; Tunali, S.; Cabuk, A. Study on the characterization of lead(II) biosorption by 
fungus Aspergillus parasiticus. Applied Biochemistry and Biotechnology, v. 136, p. 389-406, 2007.

Anon. Bioremediation of Alaskan sites on the way. Oil \& Gas Journal, v. 4, p. 42-46, 1990.

Atlas, R. M. Petroleum biodegradation and oil spill bioremediation. Marine Pollution Bulletin, v. 31, p. 178-182, 1995.

ATSDR - Agency for Toxic Substances and Disease Registry. Toxicological profile for lead. Atlanta: US Department of Health and Human Services, 2007.

Bae, W.; Mehra, R. K.; Mulchandani, A.; Chen, W. Genetic engineering of Escherichia coli for enhanced uptake and bioaccumulation of mercury. Applied and Environmental Microbiology, v. 67, p. 5335-5338, 2001.

Bae, W.; Wu, C. H.; Kostal, J.; Mulchandani, A.; Chen, W. Enhanced mercury biosorption by bacterial cells with surface-displayed MerR. Applied and Environmental Microbiology, v. 69, p. 3176-3180, 2003.

Al-Baldawi, I. A.; Abdullah, S. R. S.; Anuar.N.; Suja, F.; Mushrifah, I. Phytodegradation of total petroleum hydrocarbon (TPH) in dieselcontaminated water using Scirpus grossus. Ecological Engineering, v. 74, p. 463-473, 2015.

Barnhart, M. J.; Meyers, J. M. Pilot bioremediation tells all about petroleum contaminated soil. Pollution Engineerings, v. 21, p. 110-112, 1989.

Bartha, R.; Bossert, I. The treatment and disposal of petroleum refinery wastes. In: Atlas, R.M. (Ed.). Petroleum microbiology. New York, USA: Macmillan Publishing, 1984. p. 553-578.

Bellinger, D. C.; Bellinger, A. M. Childhood lead poisoning: The torturous path from science to policy. Journal of Clinical Investigation, v. 116, p. 853-857, 2006.

Beolchini, F.; Rocchetti, L.; Regoli, F.; Dell'Anno, A. Bioremediation of marine sediments contaminated by hydrocarbons: Experimental analysis and kinetic modeling. Journal of Hazardous Materials, v. 182, p. 403-407, 2010.

Brierley, C. L. Bioremediation of metalcontaminated surface and groundwater. Geomicrobiology Journal, v. 8, p. 201-223, 1990.
Brown, G. E. J.; Foster, A. L.; Ostergren, J. D. Mineral surfaces and bioavailability of heavy metals: A molecular-scale perspective. PNAS, v. 96, p. 3388-3395, 1999.

Bruschi, M.; Goulhen, F. New bioremediation technologies to remove heavy metals and radionuclides using $\mathrm{Fe}$ (III)-sulfate- and sulfur reducing bacteria. In: Singh, S. N.; Tripathi, R. D. (Eds.). Environmental Bioremediation Technologies. NY, USA: Springer, 2006. p. 35-55.

Carter, P.; Cole, H, Burton, J. Bioremediation: Successes and shortfalls. Proceedings of Key Bioremediation Process, 2006.

Chaudri, A. M.; McGrath, S. P.; Giller, K. E.; Rietz, E.; Sauerbeck, D. R. Enumeration of indigenous Rhizobium leguminosarum biovar trifolii in soils previously treated with metalcontaminated sewage sludge. Soil Biology and Biochemistry, v. 25, p. 301-309, 1993.

Chen, C.; Wang, J. L. Characteristics of $\mathrm{Zn}^{2+}$ biosorption by Saccharomyces cerevisiae. Biomedical and Environmental Sciences, v. 20, p. 478-482, 2007.

Cobbett, C.; Goldsbrough, P. Phytochelatins and metallothioneins: roles in heavy metal detoxification and homeostasis. Annual Review of Plant Biology, v. 53, p. 159-182, 2002.

Comte, S.; Guibaud, G.; Baudu, M. Biosorption properties of extracellular polymeric substances (EPS) towards $\mathrm{Cd}, \mathrm{Cu}$ and $\mathrm{Pb}$ for different $\mathrm{pH}$ values. Journal of Hazardous Materials, v. 151, p. 185-193, 2008.

D’Annibale, A.; Leonardi, V.; Federici, E.; Baldi, F.; Zecchini, F.; Petruccioli, M. Leaching and microbial treatment of a soil contaminated by sulphide ore ashes and aromatic hydrocarbons. Applied Microbiology and Biotechnology, v. 74, p. 1135-1144, 2007.

Das, N.; Vimala, R.; Karthika, P. Biosorption of heavy metals: An overview. Indian Journal of Biotechnology, v. 7, p. 159-169, 2008.

Dell'Anno, A.; Beolchini, F.; Rocchetti, L.; Luna, G. M.; Danovaro, R. High bacterial biodiversity increases degradation performance of hydrocarbons during bioremediation of contaminated harbour marine sediments. Environmental Pollution, v. 167, p. 85-92, 2012. 
Divya, B.; Deepak, K. M. Plant-microbe interaction with enhanced bioremediation. Research Journal of BioTechnology, v. 6, p. 72-79, 2011.

EFSA-European Food Safety Authority. Cadmium in food: Scientific opinion of the panel on contaminants in the food chain. EFSA Journal, v. 7, no. 3, 2009. https://doi.org/10.2903/j.efsa.2009.980

Evanko, C. R.; Dzombak, D. A. Remediation of metals-contaminated soil and groundwater. Environmental Sciences, v. 412, p. 1-45, 1997.

Fan, M. Y.; Xie, R. J.; Qin, G. Bioremediation of petroleum-contaminated soil by a combined system of biostimulation-bioaugmentation with yeast. Environmental Technology, v. 35, no. 1/4, p. 391-399, 2013.

Fang, L. C.; Huang, Q. Y.; Wei, X.; Liang, W.; Rong, X. M.; Chen, W. L.; Cai, P. Microcalorimetric and potentiometric titration studies on the adsorption of copper by extracellular polymeric substances (EPS), minerals and their composites. Bioresource Technology, v. 101, p. 5774-5779, 2010.

Fang, L.; Wei, X.; Cai, P.; Huang, Q.; Chen, H.; Liang, W.; Rong, X. Role of extracellular polymeric substances in $\mathrm{Cu}$ (II) adsorption on Bacillus subtilis and Pseudomonas putida. Bioresource Technology, v. 102, p. 11371141, 2011.

Gadd, G. M. Metals and microorganisms: A problem of definition. FEMS Microbiology Letters, v. 100, p. 197-204, 1992.

Gan, S.; Lau, E. V.; Ng, H. K. Remediation of soils contaminated with polycyclic aromatic hydrocarbon biodegradation. Journal of Hazardous Materials, v. 172, p. 532-549, 2009.

Garbisu, C.; Alkorta, I. Phytoextraction: A cost-effective plant-based technology for the removal of metals from the environment. Bioresource Technology, v. 77, p. 229-236, 2001.

Gaspare, L.; John, F.; Machiwa, S. J. M.; Streck, G.; Brack, W. Polycyclic aromatic hydrocarbon (PAH) contamination of surface sediments and oysters from the inter-tidal areas of Dar es Salaam, Tanzania. Environmental Pollution, v. 157, p. 24-34, 2009.
Giller, K. E.; Witter, E.; McGrath, S. P. Toxicity of heavy metals to microorganisms and microbial process in agricultural soils: A review. Soil Biology and Biochemistry, v. 30, p. 1389-1414, 1998.

Gómez Jiménez-T, R.; Moliterni, R.; Rodríguez, E.; Fernández, L.; Villaseñor, F. J. Feasibility of mixed enzymatic complexes to enhanced soil bioremediation processes. Procedia Environmental Sciences, v. 9, p. 54-59, 2011. https://doi.org/10.1016/ j.proenv.2011.11.010

Gray, E. J.; Smith, D. L. Intracellular and extracellular PGPR: Commonalities and distinctions in the plant-bacterium signaling processes. Soil Biology and Biochemistry, v. 37, p. 395-412, 2005.

Guine, V.; Spadini, L.; Sarret, G.; Muris, M.; Delolme, C.; Gaudet, J. P.; Martins, J. M. Zinc sorption to three gram-negative bacteria: Combined titration, modeling and EXAFS study. Environmental Science \& Technology, v. 40, p. 1806-1813, 2006.

Gurer, H.; Ercal, N. Can antioxidants be beneficial in the treatment of lead poisoning? Free Radical Biology \& Medicine, v. 29, p. 927-945, 2000.

Haritash, A. K.; Kaushik, C. P. Biodegradation aspects of polycyclic aromatic hydrocarbons (PAHs): A review. Journal of Hazardous Materials, v. 169, no. 1/3, p. 1-15, 2009. https://doi.org/10.1016/j.jhazmat.2009.03.1 37

Hassan, I.; Mohamedelhassan, E.; Ernest, K.; Yuan, Z. C. A Review article: Electrokinetic bioremediation current knowledge and new prospects. Advances in Microbiology, v. 6, p. 57-72, 2016. https://doi.org/10.4236/ aim.2016.61006

Head, I. M.; Jones, D. M.; Roling, W. F. M. Marine microorganisms make a meal of oil. Nature Reviews Microbiology, v. 4, p. 173182, 2006.

Head, I. M.; Swannell, R. P. J. Bioremediation of petroleum hydrocarbon. Current Opinion in Biotechnology, v. 3, p. 234-239, 1999.

Hernberg, S.; Nikkanen, J. Enzyme inhibition by lead under normal urban conditions. Lancet, v. 10, p. 63-64, 1970.

Hess, A.; Zarda, B.; Hahn, D.; Hanner, A.; Stax, D. In situ analysis of denitrifying toluene and mxylene degrading bacteria in a diesel fuel 
contaminated laboratory aquifer column. Applied and Environmental Microbiology, v. 63, p. 2136-2141, 1997.

Huckle, J. W.; Morby, A. P.; Turner, J. S.; Robinson, N. J. Isolation of a prokaryotic metallothionein locus and analysis of transcriptional control by trace metal ions. Molecular Microbiology, v. 7, p. 177-187, 1993.

Igiri, B. E.; Okoduwa, S. I. R.; Idoko, G. O.; Akabuogu, E. P.; Adeyi, A. O.; Ejiogu, I. K. Toxicity and Bioremediation of heavy metals contaminated ecosystem from tannery wastewater. Journal of Toxicology, v. 2018, Article ID 2568038, 2018. https://doi.org/10.1155/2018/2568038

Ijah, U.J.J. Accelerated crude oil biodegradation in soil by inoculation with bacterial slurry. Journal of Environmental Sciences, v. 1, p. 38-47, 2002.

Ijah, U. J. J. The potential use of chickendrop microorganisms for oil spill remediation. The Environmentalist, v. 23, p. 89-95, 2003.

Ijah, U. J. J.; Antai, S. P. Degradation and mineralization of crude oil by bacteria. Nigerian Journal of Biotechnology, v. 5, p. $79-87,1988$.

Janjua, N. Z.; Kasi, P. M.; Nawaz, H.; Farooqui, S. Z.; Khuwaja, U. B.; Hassan, N.; Jafri, S. N.; Lutfi, S. A.; Kadir, M. M.; Sathiakumar, N. Acute health effects of the Tasman Spirit oil spill on residents of Karachi, Pakistan. BMC Public Health, 6:84, 2006. https://doi.org/10.1186/1471-2458-6-84

Jarup, L. Hazards of heavy metal contamination. British Medical Bulletin, v. 68 , p. $167-182,2003$.

Kamaludeen, S. P. B. K.; Arunkumar, K. R.; Avudainayagam, S.; Ramasamy, K. Bioremediation of chromium contaminated environments. International Journal of Experimental Biology, v. 41, p. 972-985, 2003.

Kao, P. H.; Huang, C. C.; Hseu, Z. Y. Response of microbial activities to heavy metals in a neutral loamy soil treated with biosolid. Chemosphere, v. 64, p. 63-70, 2006.

Kelly, D. J. A.; Budd, K.; Lefebvre, D. D. The biotransformation of mercury in $\mathrm{pH}$-stat cultures of microfungi. Canadian Journal of Botany, v. 84, p. 254-260, 2006.
Khan, M. S.; Zaidi, A.; Wani, P. A.; Oves, M. Role of plant growth promoting rhizobacteria in the remediation of metal contaminated soils. Environmental Chemistry Letters, v. 7, p. 1-19, 2009.

Kinya, K.; Kimberly, L. D. Current use of bioremediation for TCE cleanup: Results of a survey. Remediation Journal, v. 6, p. 1-14, 1996.

Kumar, A.; Bisht, B. S.; Joshi, V. D.; Dhewa, T. Review on bioremediation of polluted environment: A management tool. International Journal of Environmental Sciences, v. 1, p. 1079-1093, 2011.

Law, R. J.; Klungsoyr, J. The analysis of polycyclic aromatic hydrocarbons in marine samples. International Journal of Environmental Policy and Decision Making, v. 13, p. 262-283, 2000.

Lloyd, J. R.; Lovley, D. R. Microbial detoxification of metals and radionuclides. Current Opinion in Biotechnology, v. 12, p. 248-253, 2001.

Lovely, D. R. Dissimilatory metal reduction: From early life to bioremediation. ASM News, v. 68, p. 231-237, 2002.

Lovley, D. R.; Philips, E. J.; Gorby, Y. A.; Landa, E. R. Microbial reduction of uranium. Nature, v. 350, p. 413-416, 1991.

Lovley, D. R.; Phillips, E. J. P. Novel mode of microbial energy metabolism: Organic carbon oxidation to dissimilatory reduction of iron or manganese. Applied and Environmental Microbiology, v. 54, p. 1472-1480, 1988.

Lyons, R. A.; Temple, J. M. F.; Evans, D.; Fone, D. L.; Palmer, S. R. Acute health effects of the sea empress oil spill. Journal of Epidemiology and Community Health, v. 53, p. 306-310, 1999.

Mejare, M.; Bulow, L. Metal-binding proteins and peptides in bioremediation and phytoremediation of heavy metals. Trends in Biotechnology, v. 19, p. 67-73, 2001.

Millar, J. A.; Battistini, V.; Cumming, R. L. C.; Carswell, F.; Goldberg, A. Lead and daminolevulinic acid dehydratase levels in mentally retarded children and in leadpoisoned suckling rats. Lancet, v. 3, p. 695698, 1970. 
Miura, N. Individual susceptibility to cadmium toxicity and metallothionein gene polymorphisms with reference to current status of occupational cadmium exposure. Industrial Health, v. 47, p. 487-494, 2009.

Needleman, H. Lead poisoning. Annual Review of Medicine, v. 55, p. 209-222, 2004.

Nies, D. H. Microbial heavy metal resistance. Applied Microbiology and Biotechnology, v. 51, p. $730-750,1999$.

O’Brien, P. Y.; Dixon, P. S. The effects of oils and oil components on algae: A review. British Phycological Journal, v. 11, p. 115142, 1976.

Odu, C. T. I. Fermentation characteristics and biochemical reactions of some organisms isolated from oil polluted soils. Environmental Pollution, v. 15, p. 271-276, 1978.

Okpokwasili, G. C.; Okorie, B. B. Biodeterioration potentials of microorganisms isolated from engine lubricating oil. Tribology International, v. 21, p. 215-220, 1988.

Oliveira, N. C.; Rodrigues, A. A.; Alves, M. I. R.; Antoniosi Filho, N. R.; Sadoyama, G.; Vieira, J. D. G. Endophytic bacteria with potential for bioremediation of petroleum hydrocarbons and derivatives. African Journal of Biotechnology, v. 12, p. 2977-2984, 2012.

Olson, J. W.; Mehta, N. S.; Maier, R. J. Requirement of nickel metabolism protein HypA and HypB for full activity of both hydrogenase and urease in Helicobacter pylori. Molecular Microbiology, v. 39, p. 176-182, 2001.

Onwubuya, K.; Cundy, A.; Puschenreiter, M.; Kumpiene, J.; Bone, B. Developing decision support tools for the selection of "gentle" remediation approaches. Science of the Total Environment, v. 407, p. 6132-6142, 2009.

Pinedo, R. C.; Aleu, J.; Collado, I. G. Pollutants biodegradation by fungi. Current Organic Chemistry, v. 13, p. 1194-1214, 2009.

Pritchard, P. H. Bioremediation as a technology; experiences with the Exxon Valdez spill. Journal of Hazardous Materials, v. 28, p. 76-79, 1991.

Pritchard, P. H.; Costa, C. F. EPA's Alaska oil spill bioremediation project. Environmental
Science \& Technology, v. 25, p. 115-130, 1991.

Roane, T. M.; Pepper, I. L. Microorganisms and metal pollution. In: Maier, R. M.; Pepper, I. L.; Gerba, C. B. (Eds.). Environmental microbiology. London: Academic Press, 2000.

Saadoun, I. M. K.; Al-Ghzawi, Z. D. Bioremediation of petroleum contamination. In: Fingerman, M.; Nagabhushanam, R. (Eds.). Bioremediation of aquatic and terrestrial ecosystems. Enfield, USA: Science Publishers, 2005.

Saranya, K.; Sundaramanickam, A.; Shekhar, S.; Swaminathan, S.; Balasubramanian, T. Bioremediation of mercury by Vibrio fluvialis screened from industrial effluents. BioMed Research International, v. 12, p. 1-6, 2017.

Sayler, G. S.; Ripp, S. Field applications of genetically engineered microorganisms for bioremediation process. Current Opinion in Biotechnology, v. 11, p. 286-289, 2000.

Sikkema, J.; Bont, J. A.; Poolman, B. Mechanisms of membrane toxicity of hydrocarbons. Microbiological Reviews, v. 59, p. 201-222, 1995.

Silver, S. Bacterial heavy metal resistance: New surprises. Annual Review of Microbiology, v. 50, p. 753-789, 1996.

Singh, S.; Kang, S. H.; Mulchandani, A.; Chen, W. Bioremediation: Environmental cleanup through pathway engineering. Current Opinion in Biotechnology, v. 19, p. 437-444, 2008.

Sloan, R. Bioremediation demonstrated at a hazardous waste site. Oil \& Gas Journal, v. 5, p. 61-66, 1987.

Smith, V. H.; Graham, D. W.; Cleland, D. D. Application of resource ratio theory to hydrocarbon biodegradation. Environmental Science \& Technology, v. 32, p. 3386-3395, 1998.

Spormann, A. M.; Widdel, F. Metabolism of alkyl benzenes, alkanes, and other hydrocarbons in anaerobic bacteria. Biodegradation, v. 11, p. 85-105, 2000.

Sposito, F. G. The chemistry of soils. In: Maier, R. M.; Pepper, I. L.; Gerba, C. B. (Eds.). Environmental microbiology. London: Academic Press, 2000. 
Strong, P. J.; Burgess, J. E. Treatment methods for winerelated ad distillery wastewaters: A review. Bioremediation Journal, v. 12, p. 70-87, 2008.

Talos, K.; Pager, C.; Tonk, S.; Majdik, C.; Kocsis, B.; Kilar, F.; Pernyeszi, T. Cadmium biosorption on native Saccharomyces cerevisiae cells in aqueous suspension. Acta Universitatis Sapientiae, Agriculture and Environment, v. 1, p. 20-30, 2009.

Tang, C. Y.; Criddle, Q. S.; Fu, C. S.; Leckie, J. O. Effect of flux (transmembrane pressure) and membranes properties on fouling and rejection of reverse osmosis and nanofiltration membranes treating perfluorooctane sulfonate containing waste water. Journal of Environmental Science and Technology, v. 41, p. 2008-2014, 2007.

Thavasi, R. Microbial biosurfactants: From an environment application point of view. Journal of Bioremediation and Biodegradation, v. 2, 100104e, 2011.

Tigini, V.; Prigione, V.; Giansanti, P.; Mangiavillano, A.; Pannocchia, A.; Varese, G. C. Fungal biosorption, an innovative treatment for the decolourisation and detoxification of textile effluents. Water, v. 2, p. $550-565,2010$.

Tunali, S.; Akar, T.; Oezcan, A. S.; Kiran, I.; Oezcan, A. Equilibrium and kinetics of biosorption of lead(II) from aqueous solutions by Cephalosporium aphidicola. Separation and Purification Technology, v. 47, p. 105-112, 2006.
Umrania, V. V. Bioremediation of toxic heavy metals using acido-thermophilic autotrophes. Bioresource Technology, v. 97, no. 10, p. 1237-1242, 2006. https://doi.org/10.1016/ j.biortech.2005.04.048

Valls, M.; Atrian, S. L. V.; La, F. Engineering a mouse metallothionein on the cell surface of Ralstonia eutropha $\mathrm{CH} 34$ for immobilization of heavy metals in soil. Nature Biotechnology, v. 18, p. 661-665, 2000.

Venosa, A. D.; Lee, K.; Suidan, M. T.; Garcia, B. S.; Cobanli, S.; Moteleb, M.; Haines, J. R.; Tremblay, G.; Hazelwood, M. Bioremediation and biorestoration of a crude oil contaminated freshwater wetland on the St. Lawrence River. Biomedical Journal, v.6, p. 261-281, 2002.

Verma, N.; Singh, M. Biosensors for heavy metals. BioMetals, v. 18, no. 1, p. 121-129, 2005.

Wu, T.; Xie, W. J.; Yi, L.; Li, X. B.; Yang, B. H.; Wang, J. Surface activity of salt-tolerant Serratia spp. and crude oil biodegradation in saline soil. Plant Soil Environ, v. 58, p. 412416, 2012. 